\title{
Refugee Status Determination Procedure in Germany, France, the U.S.A. and Australia
}

\author{
by Jean-François Durieux
}

Canada is not the only country that feels uneasy about its refugee-status determination procedures, if recent debates within international fora - notably the Executive Committee of the UNHCR - are any indication. Indeed, most industrialized nations today face the challenge of having to adjust their immigration policies to changing realities. The issue of granting asylum is a particularly sensitive part of that policy, with the extra burden of accumulated inadequacies and imperfections.

Among those countries that, together with Canada, have led the debate on the international stage and continue to do so at home, I have selected four for examination: the Federal Republic of Germany, France, the U.S.A. and Australia. The history and geography of the two European nations have made them lands of asylum, and they have entrenched the principle of political asylum in their constitutions. The latter two, like Canada, are traditional immigration countries, built to a large extent by people fleeing persecution. I have chosen a descriptive rather than a critical approach to the respective procedures and related matters. My purpose is only to provide some points of comparison and to give food for thought to all those who are interested in revising the Canadian procedures.

\section{$\bullet \bullet$}

\section{U.S.A.}

For the first time in United States history, the Refugee Act of 1980 established a statutory basis for asylum, consistent with the UN Convention. Prior to passage of the Act, grants of asylum were usually limited to those fleeing
Communist nations or certain areas of the Middle East. Today, anyone seeking to enter at a U.S. border, or physically present in the U.S., can apply for recognition of refugee status, irrespective of his/her immigration status. The procedure is widely decentralised.

Unless exclusion or deportation proceedings have been initiated, applications for asylum are filed with the District Director of the Immigration and Naturalization Services (INS). In 1983 , however, the INS modified its regulations to limit access to the District Directors (DD) and in many of the cases allowed transfer of original jurisdiction to the Immigration Judges (IJ).

The review procedure at the DD level may take anywhere from three months to two years, depending on the district's workload. However, applicants from the Soviet Union and Eastern bloc countries receive "immediate action". In each case the DD is required to seek the advice of the Bureau of Human Rights and Humanitarian Affairs, a branch of the State Department. The DD decision cannot be appealed. However, in a loophole (no doubt familiar to Canadian readers), the applicant whose in-status claim is denied is entitled, during the course of deportation proceedings, to bring up again the question of political asylum before the Immigration Judge. Asylum claims are adjudicated by the IJs in an adversarial setting, very much in the same way as normal enforcement cases. The decision of the IJ may be appealed by either party to the Board of Immigration Appeals - a body independent of the INS within the Department of Justice. A BIA determination does not entail a hearing at which the applicant appears personally - it may be appealed again in a federal court. Since the procedure was established, only a small number of individual cases have reached this level.

No claim is deemed inadmissible, nor is there any mechanism to expedite the process when a case appears manifestly unfounded. On the other hand, the refusal rate is fairly high, both at the DD $(65 \%)$ and at the IJ $(75 \%)$ levels. The administration has resorted to such measures as returning asylum seekers at land ports of entry to the contiguous foreign territory from which they came, or "interdicting" potential Haitian immigrants at sea from reaching the U.S. coast.

Clearly, the U.S. system is in serious trouble. The current backlog of claims at the DD level is around 165,000. This, however, includes the claims of 115,000 Cuban "Marielitos" (ironically, this unprecedented mass influx coincided with the passage of the Refugee Act) and of 5,000 Haitians, who for the most part enjoy special status. On the other hand, thousands of Salvadorans, Haitians and others living illegally in the country may decide to apply for asylum if apprehended.

The U.S. administration has reacted very harshly to this situation in matters ancillary to the asylum process: illegal entrants are routinely detained pending an asylum determination, and so are some applicants already within U.S. territory; the INS is permitted to withhold employment authorizations from those asylum claimants whose claims

(Continued on p. 6) 
Germany, France, the U.S.A. and

\section{Australia}

(continued from $p .5$ ) are deemed to be "frivolous". Generally speaking, asylum seekers in the U.S. do not have much of a status in the pre-asylum period and have no access to federally funded legal aid, welfare or medicare.

Once recognised, a refugee is granted a temporary resident status; the Refugee Act permits up to 5,000 "asylees" a year to adjust their status to permanent resident alien.

Amendments to the existing procedures are under careful consideration. Notably, the "Simpson-Mazzoli" bill, adopted by the Senate in 1983 , will, if endorsed by the House, introduce provisions for a single-stage appeal to a specialized administrative entity, the continuation of deportation proceedings while the suggested abusive claim is still being adjudicated, etc.

\section{Europe}

A general characteristic of European systems is to make an in-status claim the rule, and an out-of-status claim the exception. This attitude reflects a different approach to the granting of asylum than is the case in other sections of the world. The dichotomy does not always appear in terms of admissibility of the claim, but the credibility of an out-of-status claim will often be seriously diminished - apart from the obvious case of an undocumented alien seeking admission at a port of entry. Where the asylum seeker finds himself or herself illegally in the country after crossing the border unchecked, he/she is expected to report spontaneously, and at any rate without delay, to the authorities.

\section{Federal Republic of Germany}

The Asylum Procedure Act of 1982 has brought about significant revisions to the refugee-status determination procedure in the Federal Republic of Germany, which used to be famous for its endless avenues of appeal.

The core of the procedure remains the Federal Office for the Recognition of Foreign Refugees (hereafter the Federal Office), which is located in Zirndorf, land (province) of Bavaria, with a few suboffices in other parts of the Republic.

In the new format, the Aliens Police and the Border Police have a limited prescreening authority, in that the former may choose not to refer the claim to the Federal Office and the latter may deny entry if the asylum seeker has already found more than temporary protection in another country. The refusal by the Aliens Police to forward the claim to the Federal Office entails an expulsion order, which can, however, be appealed to the local Administrative Court in a summary procedure.

The applicant, who has gone through a preliminary interview at the police level, will usually be invited for a more intensive interview by the Federal Office, which the UNHCR representative has a right to attend as an observer. The Office's decision on refugee status is not collegial, but it must be motivated. If the Office rejects the application as "manifestly unfounded", a removal order ensues, which the claimant may appeal in the same summary procedure as described above in the case of non-forwarding by the Aliens Police.

A negative decision by the Federal Office without the qualification that the claim is "manifestly unfounded" may be appealed to the provincial Adminis- trative Court and further, by permission only, to the Administrative Court of Appeal; finally, cases of principle may be brought to the Federal Administrative Court, voire to the Federal Constitutional Court.

All appeals have a suspensive effect regarding the removal of the claimant. The Federal Office takes an average of six months to decide upon a case in the first instance. Delays in the Administrative Court may take up to two and a half years. The rate of acceptance by the Federal Office was $16 \%$ in 1982 . By the end of April, 1983, applications pending before the Federal Office amounted to some 16,000 . Since 1981 , the backlog is steadily decreasing due to a considerable staff reinforcement both at the Federal Office and the Administrative Courts levels.

Pending determination of their refugee status, asylum seekers in the FRG are obliged to stay in the land (province) where they submitted their application; accommodation in reception centres is favoured by several Länder. During the first two years of residence in the country, asylum seekers are not authorized to work; if in need, they receive public relief, preferably in kind, at the reception centres. Once recognized, refugees in the FRG enjoy a wide range of rights and benefits. They are issued with a residence permit of unlimited validity.

\section{France}

The French procedure for determining refugee status presents many similarities to the German one. Though its main features date back to 1952, it has undergone significant administrative "adjustments" in recent years. 
An undocumented alien seeking asylum at a port of entry is normally admitted into France; however, if he/she arrives from a third country where asylum could have been requested, and where the alien does not run the risk of being returned to the country of origin, or if the person has already been granted asylum in a third country, he/she can be denied admission by the Minister of the Interior. A claim made subsequent to clandestine entry may be declared inadmissible by the police or the municipal authorities for the same reasons. Once these obstacles are cleared, the asylum seeker must register with the Office Français pour la Protection des Réfugiés Apatrides (OFPRA) and file an affidavit documenting his claim. The OFPRA is an independent office headed by a Director, who makes decisions on all refugee claims. While OFPRA frequently makes its decisions on the basis of written documentation, the applicant may be invited for an interview.

The OFPRA currently examines over 20,000 files per year; its acceptance rate is particularly high, around $75 \%$. If the claimant has not been notified of OFPRA's decision within four months of his application, he/she is entitled to bring the claim to the Commission des Recours, which also deals with appeals against negative determinations by OFPRA. The Commission des Recours, a highly specialized quasi-judicial appellate body, is chaired by a member of the Council of State and is further composed of a representative of the OFPRA Board and the UNHCR representative in France. The appellant is always entitled to a personal hearing and may be represented by counsel. The backlog of cases is close to 7,000 , though the Board hears some 6,000 cases per year. Further appeal, to the Council of State, is only possible in cases of principle.
During the pre-asylum period, an asylum seeker receives a temporary residence permit, usually valid countrywide, and a provisional work authorization - both of which the person will retain until a final decision is made on his or her claim. Recently, however, some local authorities have tried to prevent access to work authorizations for nationals of certain countries, whose claims are deemed to be frivolous. If unemployed, a claimant is entitled to welfare subsidies for up to one year, free medical assistance and vocational training if available. Voluntary organizations run accommodation centres for asylum seekers throughout the country.

In many respects a recognized refugee enjoys the same rights as a French citizen. After three years' continuous residence in France, he/she is considered a "privileged resident".

\section{Australia}

Applications for refugee status in Australia may be made at any time and are decided upon by the Minsiter for Immigration and Ethnic Affairs upon the recommendation of a standing interdepartmental Committee for Determination of Refugee Status (DORS), established in 1978.

Examinations under oath are usually carried out by senior immigration officers in the field, and the transcript thereof is forwarded to the Committee for review. If, however, the processing officer considers that the claim is abusive or manifestly unfounded, or yet incompatible with Convention and Protocol (particularly with regard to the exclusion clauses of Article 1 of the
Convention), a short synopsis of the case is forwarded with the officer's assessment to the Committee. If at least one Committee member (including the UNHCR observer) requests that the application be fully reviewed by the Committee, normal processing will be initiated. (In practice, this is often the case.)

The DORS Committee is composed of senior officials from the Departments of Immigration and Foreign Affairs and the Offices of the Attorney-General and the Prime Minister, with the UNHCR representative attending as an observer. The procedure does not provide for a formal appeal, but the Minister may, in the light of additional information, refer any case back to the Committee for reconsideration. The Committee presently has a backlog not exceeding 100 applications.

Asylum seekers in Australia are usually granted a temporary residence permit with no geographical restriction. Only in cases of extreme hardship are work authorizations granted. Once recognized, a refugee is expected to apply for permanent residence; the processing of the application takes an average of six months, during which time work authorizations are easier to obtain.

Compared with the other country procedures we reviewed, the Australian procedure appears both relatively unsophisticated and fairly efficient. But one must bear in mind that Australia's geographical isolation and strict entry controls have succeeded in preventing the overload that affects asylum procedures in most other industrialized nations.

\section{$\bullet \bullet$}

Jean-François Durieux works as a Legal Officer for the United Nations High Commissioner for Refugees, Branch Office for Canada. 